\title{
ARAŞTIRMA / RESEARCH \\ Pulmoner ve ekstrapulmoner örneklerde tüberkülozun erken tanısı ve rifampisin direncinin tespiti için geneXpert MTB/RIF testinin değerlendirilmesi
}

Evaluation of the geneXpert MTB/RIF assay for early diagnosis of tuberculosis and detection of rifampicin resistance in pulmonary and extrapulmonary specimens

\author{
Ali Albay ${ }^{1}$, Mustafa Güney ${ }^{1}$, Kemal Tekin¹, Özgül Kısa ${ }^{1}$, Ali Korhan Sığ ${ }^{1}$ \\ ${ }^{1}$ Gülhane Askeri Tip Akademisi Tip Fakültesi, Tıbbi Mikrobiyoloji Anabilim Dalı, Ankara, Turkey
}

Cukurova Medical Journal 2016;41(3):548-553.

\begin{abstract}
Purpose: The emerging of multi-drug resistant strains of Mycobacterium tuberculosis complex and the resurgence of tuberculosis have forced new methods for diagnosis and antimicrobial susceptibility to be developed. In this study, we evaluated a recently marketed diagnostic technique, GeneXpert MTB/RIF test, in terms of identifying Mycobacterium tuberculosis complex and detecting rifampicin resistance from clinical samples.

Material and Methods: In our study, GeneXpert MTB/RIF assay was compared with conventional and automated culture methods. 389 various clinical samples (171 pulmonary and 218 ekstrapulmonary samples) were cultured with BACTEC MGIT 960 culture system and Löwenstein-Jensen medium and were tested with GeneXpert MTB / RIF test.
\end{abstract}

Results: 23 samples were positive for Mycobacterium tuberculosis complex by GeneXpert MTB/RIF test, but 22 samples were positive for Löwenstein-Jensen medium and BACTEC MGIT 960 culture system. 2 of 23 samples were detected rifampicin resistant at the first study, but restudying of these samples resulted as rifampicin resistant for only one sample. According to culture findings of al pulmonary samples, the sensitivity and specificity for GeneXpert MTB / RIF test were both 100\% (16/16). The sensitivity and specificity for extrapulmonary samples were $83.3 \%$ and $99.5 \%$, respectively.

Conclusion: GeneXpert MTB / RIF test is an effectual automated molecular diagnostic technique with its successful and reliable performance in early diagnosis of tuberculosis and detecting multi-drug resistant strains.

Key words: Tuberculosis, GeneXpert MTB/RIF, rifampicin resistance.
Öz

Amaç: Mycobacterium tuberculosis kompleks'in çok ilaca dirençli suşlarının ortaya çıkması ve tüberkülozun yeniden önem kazanması, yeni tanı ve antibiyotik duyarlılık test yöntemlerinin geliştirilmesini teşvik etmiştir. Biz de çalıșmamızda bu amaçla son zamanlarda geliștirilmiş bir tanı yöntemi olan GeneXpert MTB/RIF testini, klinik örneklerden M. tuberculosis kompleksin tanımlanması ve rifampisin direncinin saptanmasında değerlendirdik.

Gereç ve Yöntem: Çalışmamızda klasik ve tam otomatize kültür yöntemleri ile GeneXpert MTB/RIF testi karşılaştırıldı. 389 adet çeşitli klinik örneklerin (171 adet pulmoner ve 218 adet ekstrapulmoner) kültürleri, BACTEC MGIT 960 kültür sistemi ve Löwenstein-Jensen besiyeri ile yapıldı. Aynı zamanda GeneXpert MTB/RIF sistemi ile bu klinik örnekler test edildi.

Bulgular: GeneXpert MTB/RIF testi ile 23 örnek, Löwenstein-Jensen besiyeri ve BACTEC MGIT 960 kültür sistemi ile 22 hasta örneği pozitif olarak tespit edildi. İki M. tuberculosis kompleks suşu GeneXpert MTB/RIF testi ile başlangıçta rifampisin dirençli olarak belirlendi, ancak testin tekrarlanması ile iki suştan biri duyarlı olarak tespit edildi. Kültür sonuçlarına göre hem yayma negatif hem de pozitif pulmoner örnekler için GeneXpert MTB/RIF testinin duyarlllığ1 \%100 (16/16) olarak bulundu. Testin ekstrapulmoner örnekler için duyarlllığ1 ve özgüllüğü, sirasiyla $\% 83.3$ ve $\% 99.5$ olarak belirlendi.

Sonuç: GeneXpert MTB/RIF testinin, tüberkülozun erken tanısında ve çok ilaca dirençli suşların tespitindeki başarılı sonuçlarıyla tüberküloz laboratuvarlarında etkin bir şekilde kullanılabilecek otomatize moleküler bir tanı testi olduğu düşünülmektedir.

Anahtar kelimeler: Tüberküloz, GeneXpert MTB/RIF, rifampisin direnci. 


\section{GİRİŞ}

Her yıl yaklaşı 9.6 milyon yeni olgu sayısı ve 1.5 milyon hastanın ölümüyle sonuçlanan tüberküloz (TB), tüm dünyada ciddi bir halk sağlığ1 sorunu olarak halen önemini korumaktadır ${ }^{1}$. Etken olan Mycobacterium tuberculosis kompleks (MTBC) üyeleri tarafindan oluşturulan TB hastalığında, olguların çoğu pulmoner hastalıktır. Ekstrapulmoner hastalığa da neden olmakla birlikte, düşük insidanslı ülkelerde pulmoner/ekstrapulmoner TB oranı \%15 civarındadır. Üstelik ekstrapulmoner TB olgularında örneklerin çoğunun invaziv girişimler sonucu alınması ve ilave olarak örnekteki basil yükünün daha az olması tanıda zorluklara yol açmaktadır ${ }^{2}$. Son yıllarda giderek artan ilaç direnci ise TB tedavisinde ciddi bir sorun olmaya devam etmektedir. Dünya Sağlık Örgütü (DSÖ)'nün Avrupa bölgesi verilerine göre TB'de çok ilaca dirençli (ÇID) etken oranı ülkeden ülkeye farklılık göstermekle birlikte, bazı ülkelerde \% 28'lere kadar varmaktadir. Dolayısıyla taninın hizla konularak etkin tedaviye başlanması TB kontrol programlarının başarı ile uygulanabilmesi için ön şarttır ${ }^{1,3}$.

Tanı için kullanılan yayma mikroskopisi oldukça hızlı ve ucuz bir yöntem olmasına karşın düşük duyarlılığı (\%45-80) ve negatif prediktif değeri açısından sınırlı bir değeri vardır. Tanı için altın standart kültürdür ancak, sonuç raporunun çıkması için geçen süre 2 ila 8 hafta arasında değişmektedir ${ }^{4,5,6}$. Bu ise özellikle şiddetli olguların yönetiminde sorunlara yol açabilmektedir ${ }^{7}$. Bu nedenle son yıllarda TB'nin tanısını ve ilaç direncini hızlı ve doğru bir şekilde tespit edebilmemizi sağlayan pek çok moleküler test yöntemi geliştirilmiştir. Bunlardan biri olan GeneXpert MTB/RIF (Cepheid, Sunnyvale, CA, $\mathrm{ABD})$ test sistemi; bakteriyel lizis, DNA ekstraksiyonu, heminested PCR yöntemi ile genomik amplifikasyonu ve semikantitatif MTBC tespitinin tek kullanımlık plastik bir kartuş içinde sonuçlandırılması esasına dayanmaktadır ${ }^{8,9}$. Aynı zamanda bu kartuş içinde rifampisin (RIF) direncine de bak1labilmektedir.

Temel olarak RIF direnci rpoB geninin 81 bp'lik çekirdek bölgesindeki beş gen mutasyonu ile oluşur. MTBC'de tek başına RIF direnci nadirdir ve RIF dirençli olguların \%90'ından fazlasında izoniyazid (INH) direnci de eşlik ettiğinden bu yöntem sayesinde çok ilaca dirençli (ÇID) MTBC suşlarının saptanması için iyi bir belirteç olduğu ifade edilmektedir ${ }^{9,10}$. Test örneği kartuşa yerleştirildikten sonra iki saat içerisinde sonuç vermektedir ${ }^{11,12,13}$.

$\mathrm{Bu}$ çalışmanın amacı yayma pozitif ve negatif, pulmoner ve ekstrapulmoner klinik örneklerde MTBC tanisi ve RIF direncinin saptanmasinda GeneXpert MTB/RIF (Cepheid, Sunnyvale, CA, $\mathrm{ABD})$ test sisteminin performansinin değerlendirilmesidir.

\section{GEREÇ VE YÖNTEM}

Çalışma 1200 yatak kapasiteli Gülhane Askeri Tıp Fakültesi Tibbi Mikrobiyoloji AD Mikobakteriyoloji laboratuvarında (Ankara/Türkiye) yapıldı. Çalışma öncesinde Gülhane Askeri Tip Akademisi Etik Kurulu'nun onayı alındı. Çalışmaya rutin hasta muayenesi ve tedavisi sirasinda gelen toplam 389 (171 adet pulmoner ve 218 adet ekstrapulmoner) klinik örnek dahil edildi.

\section{Örneklerin işlenmesi ve kültür}

Klinik örneklerin N- acetyl-L-cysteine ve \%4'lük sodyum hidroksit kullanılarak homojenizasyonu ve dekontaminasyonu yapıldıktan sonra mikroskopik incelenme için Ehrlich-Ziehl-Neelsen (EZN) boyama yöntemi kullanıldı. Normalde steril kabul edilen (plevra s1visı, sinovyal sıvı gibi) örnekler, dekontaminasyon işlemine tabi tutulmadan ya santrifüj edildikten sonra ya da örnek miktarı az ise doğrudan ekim işlemi için kullanıldı. Kültür için işlenmiş örneklerden, katı besiyeri olarak LöwensteinJensen (LJ) besiyerine (Salubris, Türkiye) $200 \mu l$. ve içeriğinde modifiye Middlebrook 7H9 siv1 besiyeri bulunan Mycobacteria Growth İndicator Tube (MGIT) tüplerine (Becton Dickinson, ABD), üreticilerin önerileri doğrultusunda ekim yapıldı. Katı besiyerine yapılan ekimler 8 hafta, sıvı besiyeri ise BACTEC MGIT 960 (Becton Dickinson, ABD) ile 6 hafta inkübe edildi. Bu süre sonunda üreme olmaması halinde örnek negatif olarak değerlendirildi. Üreme olduğunda ise MTBC tanımlanması için MPT 64 antijenini saptayan immünokromatografik yöntem (BD MGIT TB Identification Test, Becton Dickinson, ABD) kullanıld1.

\section{GeneXpert MTB/RIF Testi}

GeneXpert MTB/RIF testi ise üretici firma önerileri doğrultusunda yapıldı. Dekontamine edilmiş klinik örnekler steril bir tüpte 3:1 oranında, dekontamine edilmeyen örnekler ise 2:1 oraninda sodyum 
hidroksit ve izopropanol içeren örnek reaktifi (SR) ile karıştırıldı. Daha sonra 10-15 kez elle çalkalayarak 15 dakika oda 1sısında inkübe edildi. Buraya kadar yapılan işlemler ile testin elle yapılan kısmı sona erdi. Bundan sonra her bir klinik örnekten $2 \mathrm{ml}$ alarak kartuşa aktarıldı ve dolu kartuş GeneXpert cihazına yerleştirildi. Cihaz, yaklaşı 120 dakika sonra testi sonuçlandırdı ve elde edilen sonuçlar değerlendirildi.

\section{İstatistiksel Analiz}

Verilerin tanımlanmasında sayı ve yüzde değerleri kullanıldı. GeneXpert MTB/RIF testinin sonuçları, TB tanısında altın standart olan kültür yönteminin sonuçlarıyla karşılaştırıldı ve duyarlılık, özgüllük, negatif prediktif değer (NPD) ve pozitif prediktif değerler (PPD) hesaplanarak performans değerlendirmesi yapıldı.

\section{BULGULAR}

Çalışmaya 389 klinik örnek dahil edildi. Bu örneklerin 171'i (\%43.9) pulmoner, 218'i (\%56.1) ektrapulmoner kökenli idi. Pulmoner örneklerin 131'i balgam, 34'ü bronkoalveolar lavaj (BAL) ve 6's1 da açlık mide suyu idi. Ekstrapulmoner örneklerin ise 87'si idrar, 17'si beyin omurilik sivis1, 33'ü doku örneği, 19'ü yara ve abse aspirat, 3’ü ejakülat, 4'ü kemik iliği ve 55 'i steril vücut sıviları (15'i parasentez sivisi, 21'i plevral siv1, 13'ü perikadiyal ve 6's1 da eklem sıvisı) idi.

Toplam 389 örneğin 22'si MTBC yönünden kültür pozitif olarak, 367'si kültür negatif olarak tespit edildi. Bunların 16's1 pulmoner örneklerden 6's1 da ekstrapulmoner örneklerden izole edildi. Kültür pozitif olan 16 pulmoner örneğin yayma mikroskopisi, sadece 6'sında pozitif olarak tespit edildi. Aynı şekilde kültür pozitif olan ekstrapulmoner 6 örneğin ise 2'sinin yayma mikroskopisi pozitif olarak bulundu.

GeneXpert MTB/RIF yöntemi ile 389 örneğin 23'ü pozitif olarak tespit edildi. Kültür negatif ancak GeneXpert MTB/RIF testinin pozitif bulunduğu bir BAL örneği ile bir lenf nodu biyopsisi dışındaki tüm örnekler kültür sonuçları ile uyumlu idi (yalancı pozitif).

Öte yandan kültür pozitif ekstrapulmoner örneklerden biri GeneXpert MTB/RIF testi ile negatif olarak tespit edilmiştir (yalancı negatif). Kültür sonucu pozitif olan 22 örnekten ikisinin RIF direnci GeneXpert MTB/RIF testi ile pozitif olarak bulundu. Ancak doğrulama maksadiyla yapılan BACTEC MGIT 960 kültür sistemi ile yalnızca bir tanesi pozitif olarak tespit edildi. Altın standart olan kültür yöntemi ile karşılaştırıldığında mikroskopi negatif ve pozitif pulmoner ve ekstrapulmoner örneklerde GeneXpert MTB/RIF testi ile elde edilen duyarlılık, özgüllük, pozitif ve negatif prediktif değerleri Tablo 1'de verilmiştir.

\section{TARTIŞMA}

TB’nin kontrolünde en önemli basamaklardan birisi de hızlı ve doğru tanıdır. Bu çalışmada TB tanısı için pulmoner ve ekstrapulmoner örnekler GeneXpert MTB/RIF testi ile çalışıldı ve özellikle yayma pozitif örneklerde testin özgüllük ve duyarlllığ1 \%100 olarak bulundu. Pulmoner ve ekstrapulmoner örneklerin tümü birlikte değerlendirildiğinde GeneXpert MTB/RIF testinin duyarlllı̆̆1 \%95, özgüllüğü \%99, pozitif prediktif değeri $\% 93$ ve negatif prediktif değeri ise \%99 olarak tespit edildi. Ayr1 ayr1 değerlendirildiklerinde ise; duyarlılık, özgüllük, pozitif prediktif ve negatif prediktif değerleri, pulmoner ve ekstrapulmoner örnekler için sırasılya; $\% 100$ ve $\% 83.3, \% 99.3$ ve $\% 99.5, \% 94.1$ ve $\% 85.7$, $\% 100$ ve $\% 99.5$ olarak saptand1.

$\mathrm{Bu}$ alanda yapılmış ulusal çalışma sayısının az olmasına karşın GeneXpert MTB/RIF testinin duyarlılığ1 \% 73.9-96, özgüllüğü ise \% 98-98.6 olarak bildirilmiştir ${ }^{14,15}$. Ancak uluslararası çalışmalarda ise duyarlılığın \% 90.4 (\%43 ile \%100), özgüllüğün ise $\% 98.4$ (\%92 ile \%100) olduğu görülmektedir. Araştırmacılar özellikle duyarlılıktaki bu farklılığın örnek sayısına, çalışmanın yapıldığı bölgedeki TB insidansına, örneğin pulmoner veya ekstrapulmoner kökenli olmasına ve örnekteki basil yükünün değişkenliğine bağlı olabileceğini açıklamışlardır ${ }^{16,17}$.

Çalıșmamızda da en dikkat çekici bulgu, testin duyarlılı̆̆ının pulmoner örneklerde ekstrapulmoner örneklere göre daha yüksek olduğudur. Çalışmada elde ettiğimiz veriler hem ulusal hem de uluslararası veriler ile uyumludur. Çalıșmamızda toplam $171 \%$ 43.9) pulmoner örnek değerlendirildi. Özellikle kültür pozitif 16 örnek arasindan yayma negatif 10 örnek değerlendirildiğinde testin duyarlılığ $\% 100$ ve özgüllüğü \%99.3 olarak bulundu. Pulmoner örneklerde GeneXpert MTB/RIF testinin duyarlılığını Zeka ve arkadaşlaşları ${ }^{4} \% 74.2$, Bunsow ve $\operatorname{arkadaşlar1}^{6} \% 71.4$ ve Bodmer ve arkadaşlar1 ${ }^{18}$ da $\% 90.2$ olarak tespit etmişlerdir. İoannidis ve arkadaşlari ${ }^{19}$ ise sadece yayma negatif 80 pulmoner 
örnek ile çalışmışlar; kültür sonuçları ile karşılaştırıldığında 29 örneği kültür ve GeneXpert MTB/RIF ile pozitif, 3 örneği ise kültür ile pozitif, GeneXpert MTB/RIF testi ile negatif olarak tespit etmişler ve testin duyarlılı̆̆ını \%90.6 olarak bulmuşlardır. Çalışmamızda kültür negatif 155 örneğin 1'inde GeneXpert MTB/RIF ile pozitif olarak sonuç elde edildi. Bu yalancı pozitifliğin nedeni olan hasta örneği araştırıldığında, hastanın daha önce TB hikayesi olduğu, ancak çok uzun süredir ilaç tedavisi almadığı ve klinik iyileşmenin sağlandığ1 öğrenilmiştir. Dolayısı ile bu pozitifliğin ölmüş basil DNA'sına bağlı olabileceği değerlendirilmektedir ${ }^{4,6}$.

Tablo 1. Kültür ve mikroskopi sonuçlarına göre GeneXpert MTB/RIF testinin duyarlılığı, özgüllüğü, pozitif ve negatif prediktif değerleri.

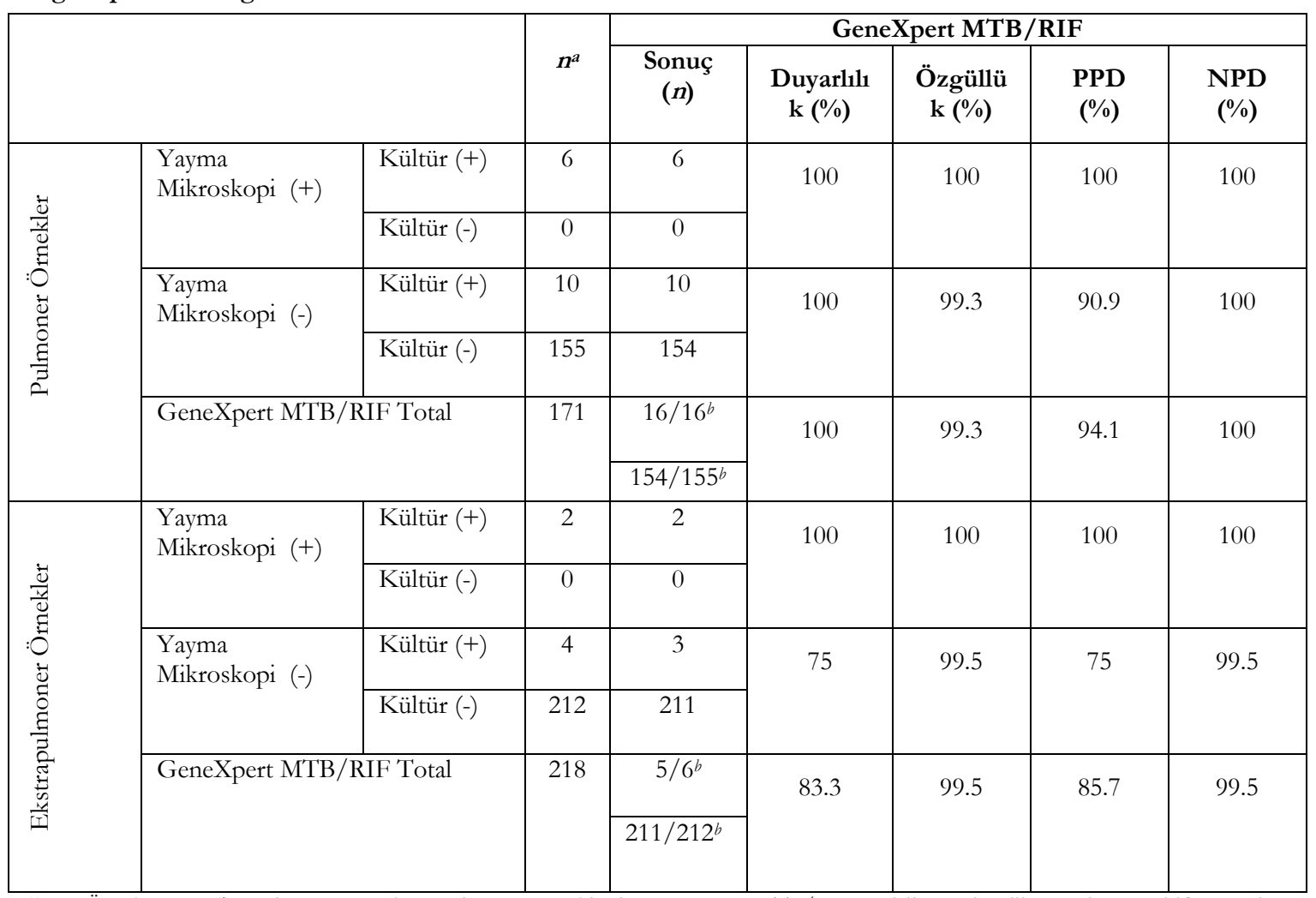

(a) $n$ : Örnek sayısi; (b) Pulmoner ve Ekstrapulmoner örneklerde GeneXpert MTB/RIF testi ile tespit edilen toplam pozitif ve toplam negatif sayılar belirtilmiştir.

Çalışmaya alınan klinik örneklerin \%57.1'i $(\mathrm{n}=218)$ ekstrapulmoner örneklerden oluşmaktadır. Kültür pozitif olan 6 örneğin 2'si aynı zamanda yayma pozitif olduğundan kültür ve yayma pozitif örneklerde GeneXpert MTB/RIF testinin duyarlılı̆̆1 $\% 100$ olarak bulundu. Buna karşın yayma negatifkültür pozitif dört örnekten sadece birini GeneXpert MTB/RIF testi tespit edemedi. Bu çalışmada pozitif örnek sayısının az olmasina rağmen yayma negatifkültür pozitif örneklerde testin duyarlılığ1 $\% 75$ olarak bulundu. Yayma sonuçları dikkate alınmadan ekstrapulmoner örneklerin tamaminda GeneXpert MTB/RIF testinin duyarlılı̆̆1 \%83.3 olarak belirlendi. Benzer şekilde ekstrapulmoner örneklerde
GeneXpert MTB/RIF testinin duyarlıllğını Zeka ve arkadaşlar1 ${ }^{4} \% 63$, Bunsow ve arkadaşlar1 ${ }^{6} \% 20$ ve Chang ve arkadașlarr $^{17}$ ise $\% 70.7$ olarak belirtmişlerdir. Yapılan çalışmalar incelendiğinde ekstrapulmoner örneklerdeki testin duyarlllı̆̆ının düşük olmasını, basil yükünün azlığına, homojenizasyon işlemlerinin iyi olmamasına bağlamışlar ve bu örneklerin yeterli miktar alınması ve iyi konsantre edilmesi ile duyarlılığın bir miktar arttırılabileceği belirtilmiștir ${ }^{12}$.

$\mathrm{Bu}$ çalışmada kültür pozitif, GeneXpert MTB/RIF testi ile negatif olarak sonuçlanan ekstrapulmoner örnek lenf nodu biyopsisidir. Chang ve arkadaşlar1 ${ }^{17}$ 
15 farklı araştırmanın çalışmalarını dahil ettikleri meta-analiz çalışmasında yalancı negatiflik oranının \%9.6 olarak tespit etmişlerdir. Bu yalancı negatiflik oranının en önemli nedenini ise örneklerin içindeki basil yükünün analitik saptama limiti olan 131 CFU/ml'nin altında olmasından kaynaklandığını belirtmişlerdir.

Pulmoner örneklere benzer şekilde kültür negatif ekstrapulmoner örneklerden biri de (lenf nodu biyopsisi) GeneXpert MTB/RIF testi ile pozitif (yalancı pozitif) olarak tespit edildi. Benzer sonuçları araştırmacılar da aynı şekilde bulmuşlardır. Zmak ve arkadaşları $^{20}$ toplam 361 pulmoner ve ekstrapulmoner örnek ile yaptıkları çalışmada kültür negatif, GeneXpert MTB/RIF testi pozitif olarak üç örnek (ikisi BOS, diğeride doku örneği) tespit etmişlerdir. $\mathrm{Bu}$ uyumsuz sonuçların nedenini ise, ikisinin antitüberküloz tedavi gören hastalara ait olmasına, diğerinin ise örnekteki basil yükünün azlığından kaynaklanmasına bağlamışlar ve bu örneğin daha sonra tekrarlandığında pozitifleştiğini tespit etmişlerdir. Özkütük ve arkadaşları ${ }^{14}$ ise 1611 pulmoner örnekten 18'inde ve 1028 ekstrapulmoner örnekten ise 16'sında yalanc1 pozitiflik saptamışlardır. Aynı çalışmada ise yalancı pozitiflik oranının \% 1.6 olduğunu ve bunun da en çok tüberküloz hikayesi olan hastalarda tedavi sonras1 ölü basilleri DNA'sının salınımına veya atılımına bağladıkları görülmüştür. Meta-analiz çalışmalarına göre yalancı pozitiflik oranının \%1.6 olarak belirlendiği bildirilmiş ve bunun nedeninin de en çok TB hikayesi olan hastalarda ölmüş basil DNA'sına veya subklinik relapsa bağlı olabileceği ifade edilmektedirr ${ }^{16,17}$. Ayrıca Hillemann ve arkadașlarr ${ }^{2}$ örnek kontaminasyonun da yalancı pozitiflik nedeni olabileceğini ifade etmiştir.

GeneXpert MTB/RIF testinin duyarlılığının (pulmoner örneklerde \%100, ekstrapulmoner örneklerde ise \%83.3) ekstrapulmoner örneklerde daha düşük olduğu saptand1. Bu da, GeneXpert MTB/RIF testi için DNA ekstraksiyonu ve örnek hazırlanması açısından pulmoner örneklerin ekstrapulmoner örneklere göre daha uygun olduğunu düşündürmektedir. Bu durumu çözmek için proteinaz $K$ ile inkübasyonun ve buffer solüsyonun kapasitesinin arttırılmasının faydalı olabileceği değerlendirilmiştir ${ }^{17}$.

TB'nin laboratuvar tanısı için kullanılan diğer moleküler yöntemler ile karşılaştırıldığında GeneXpert MTB/RIF testinin en önemli avantajlarından biri de, testin aynı zamanda RIF direncine bakabilmesidir. RIF'e dirençli izolatların \%95'inden fazlasinda, dirençten rpoB gen bölgesindeki mutasyon sorumludur ve GeneXpert MTB/RIF testi de, bu rpoB gen bölgesindeki 81-baz çiftlik bölgenin tanınması esasına dayanmaktadır ${ }^{9,10}$. Bilindiği üzere, ÇID-TB tanısı alabilmesi için bir izolatın RIF ve INH'nın her ikisine birden aynı anda dirençli olması gerekmektedir ${ }^{21,22}$. Tek başına RIF direncinin diğer ilaçlara oranlara çok daha nadir görülmesinden ve RIF'e dirençli suşların \%90'ından fazlasında INH direncinin de birlikte görülmesinden dolayı, RIF direncinin varlığı ÇID-TB'nin tanısında önemli bir gösterge olarak kabul edilir ${ }^{9,10}$. Buna göre de ÇID-TB tanısını koymak için RIF direncinin tespitinin iyi bir belirteç olduğu ve GeneXpert MTB/RIF testinin de ÇID-TB tanısında güvenle kullanılabileceği değerlendirilmektedir ${ }^{12,14,17}$. Çalışmamızda 22 MTBC suşunun 2'sinde GeneXpert MTB/RIF ile RIF direnci pozitif olarak tespit edildi. Ancak doğrulama amaciyla kullanılan BACTEC MGIT 960 kültür sistemi ile yapılan duyarlılık testinde dirençli olarak belirlenen iki suştan sadece birisinde RIF direnci saptandi. BACTEC MGIT 960 kültür sistemi ile RIF direnci negatif bulunan ve GeneXpert MTB/RIF ile RIF direnci pozitif olarak saptanan bu izolatın dizi analizi yapılmadı. Ancak Marlowe ve ark.larının ${ }^{13}$ yaptığ gibi suşun MGIT tüplerinde tekrar subkültürünün yapilarak GeneXpert MTB/RIF testinin tekrarlanmasiyla RIF'e duyarlı olarak bulundu.

MTBC izolatlarının \%5'inde $r p o B$ gen bölgesinin dışındaki bir bölgede mutasyon olduğundan ${ }^{9}$ ve bu tür izolatların GeneXpert MTB/RIF testi ile saptanamadığından ${ }^{10}$ dolayı uyumsuz sonuçların incelenebilmesi için DNA dizi analizi yapılması gereklidir. Bu durum çalışmamızın kısıtlılığıdır.

Çalışmamızın en önemli kısıtlllıklarından biri de örnek büyüklüğünün azlığıdır. Türkiye'de 2013 y1lında yeni tanı alan TB'li hasta sayısı 12352'dir. Bunların 4938'ine ilaç duyarlılık testi yapılmış ve 123'ü ÇİD-TB olarak tanı almıştır. Aynı yıl içinde Türkiye için toplam (yeni ve eski vakaların tümü) ÇID-TB’li hasta sayısı $228 \quad(\% 4.1)$ olarak saptanmıştır ${ }^{23}$. Düşük prevelanslı bir ülke olmamız ve dolayısıyla vaka sayılarının az olması nedeniyle, yayma negatif örnek türlerinin çeşitliliğinin arttırilmas1 ile testin tekrarlanmasinin daha aydınlatıcı ve daha doğru bir değerlendirme olanağı sağlayacağ́1 düşünülmektedir.

Sonuç olarak; çalışmada kullanılan GeneXpert MTB/RIF testinin, duyarlılık ve özgüllük açısından 
pulmoner ve ekstrapulmoner örneklerde oldukça başarılı bir performans gösterdiği değerlendirilmiştir. Ayrıca testin basit bir eğitimle uygulanabilirliği ve çok fazla deneyim gerektirmemesi, sonuçların iki saat gibi kisa bir sürede verilebilmesi ve bu nedenle kolaylikla rutin laboratuvar hizmetlerinde kullanılabilmesi ise bir başka önemli avantajıdır. Tüm bunlara ilaveten DSÖ, TB'li hasta yükünün fazla olduğu bölgelerde, hasta örneklerinde MTBC varlığının ve aynı zamanda RIF direnç durumunun ortaya konması için bu testi önermektedir.

\section{KAYNAKLAR}

1. World Health Organization (WHO). Global Tuberculosis Report 2015. WHO/HTM/TB/2015.22, 2015.

2. Hillemann D, Rüsch-Gerdes S, Boehme C, Richter E. Rapid molecular detection of extrapulmonary tuberculosis by the automated GeneXpert MTB/RIF System. J Clin Microbiol. 2011;49:1202-5.

3. Zignol M, van Gemert W, Falzon D, Jaramillo E, Blanc L, Raviglione M. Modernizing surveillance of antituberculosis drug resistance: from special surveys to routine testing. Clin Infect Dis. 2011;52:901-6.

4. Zeka A, Taşbakan S, Çavuşoğu C. Evaluation of the GeneXpert MTB/RIF assay for rapid diagnosis of tuberculosis and detection of rifampin resistance in pulmonary and extrapulmonary specimens. J Clin Microbiol. 2011;49:4138-41.

5. Moure R, Muñoz L, Torres M, Santin M, Martín R, Alcaide F. Rapid detection of mycobacterium tuberculosis complex and rifampin resistance in smear-negative clinical samples by use of an integrated real-time PCR method. J Clin Microbiol. 2011;49:1137-9.

6. Bunsow E, Ruiz-Serrano MJ, LópezRoa P, Kestler M, Viedma DG, Bouza E. Evaluation of GeneXpert MTB/RIF for the detection of Mycobacterium tuberculosis and resistance to rifampin in clinical specimens. J Infect. 2013:68:338-43.

7. Alvarez-Uria G, Azcona JM, Midde M, Naik PK, Reddy S, Reddy R. Rapid diagnosis of pulmonary and extrapulmonary tuberculosis in HIV-infected patients. comparison of LED fluorescent microscopy and the GeneXpert MTB/RIF assay in a district hospital in India. Tuberc Res Treat. 2012;2012:932862.

8. Cepheid $\AA$ 2015. Xpert ${ }^{\circledR}$ MTB/RIF Dx System Operator Manual. Cepheid, Sunnyvale, CA, ABD

9. Lawn, S. D.; Nicol, M.P. Xpert ${ }^{\circledR}$ MTB/RIF assay: development, evaluation and implementation of a new rapid molecular diagnostic for tuberculosis and rifampicin resistance. Future microbial. 2011,6:106782.

10. Kalokhe, A.S., Shafiq, M., Lee, J.C. et al., Multidrugresistant tuberculosis drug susceptibility and molecular diagnostic testing: a review of the literature. Am J Med Sci. 2013;345:143-8.

11. Boehme CC, Nabeta P, Hillemann D, Nicol MP, Shenai S, Krapp F et al. Rapid molecular detection of tuberculosis and rifampin resistance. $\mathrm{N}$ Engl J Med. 2010;363:1005-15.

12. Lawn SD, Nicol MP. GeneXpert ${ }^{\circledR}$ MTB/RIF assay: development, evaluation and implementation of a new rapid molecular diagnostic for tuberculosis and rifampicin resistance. Future Microbiol. 2011;6:106782.

13. Marlowe EM, Novak-Weekley SM, Cumpio J, Sharp SE, Momeny MA, Babst A et al. Evaluation of the CepheidGeneXpert MTB/RIF assay for direct detection of mycobacterium tuberculosis complex in respiratory specimens. J Clin Microbiol. 2011;49:1621-3.

14. Özkütük N, Sürücüoğlu S. Orta prevalanslı bölgede akciğer ve akciğer dışı tüberküloz tanısında GeneXpert MTB/RIF testinin değerlendirilmesi. Mikrobiyol Bul. 2014;48:223-32.

15. Çiftçi IH, Aslan MH, Aşık G. Evaluation of GeneXpert MTB/RIF results for the detection mycobacterium tuberculosis in clinical samples. Mikrobiyol Bul. 2011;45:43-7.

16. Walusimbi S, Bwanga F, De Costa A, Haile M, Joloba M, Hoffner S. Meta-analysis to compare the accuracy of GeneXpert, MODS and the WHO 2007 algorithm for diagnosis of smear-negative pulmonary tuberculosis. BMC Infect Dis. 2013;13:507.

17. Chang K, Lu W, Wang J, Zhang K, Jia S, Li F, Deng $\mathrm{S}$, Chen M. Rapid and effective diagnos is of tuberculosis and rifampicin resistance with GeneXpert MTB/RIF assay: a meta-analysis. J Infect 2012;64:580-8.

18. Bodmer T, Ströhle A. Diagnosing pulmonary tuberculosis with the GeneXpert MTB/RIF Test. J Vis Exp. 2012;62:3547.

19. Ioannidis P, Papaventsis D, Karabela S, Nikolaou S, Panagi M, Raftopoulou E et al. Cepheid GeneXpert MTB/RIF assay for mycobacterium tuberculosis detection and rifampin resistance identification in patients with substantial clinical indications of tuberculosis and smear-negative microscopy results. J Clin Microbiol. 2011;49:3068-70.

20. Zmak L, Jankovic M, Jankovic VK. Evaluation of GeneXpert MTB/RIF assay for rapid molecular diagnosis of tuberculosis in a two-year period in Croatia. Int J Mycobacteriol. 2013;2:179-82.

21. Baylan O. Çok ilaca dirençli tüberkülozdan sonra yaygın ilaca dirençli ve tüm ilaçlara dirençli tüberküloz formları: eski hastalığın yeni yüzleri. Mikrobiyol Bul. 2011;45:181-95.

22. Tahaoğlu K. çok ilaca dirençli tüberküloz (ÇİD-TB). In Tüberküloz (Eds Ş Özkara, Z Kılıçaslan):534-53. İstanbul, Aves Yayıncilık, 2010.

23. Türkiye Halk Sağlığı Kurumu. TBC Daire Başkanlığı. Verem Savaş Raporu. Ankara, THSK, 2013. 